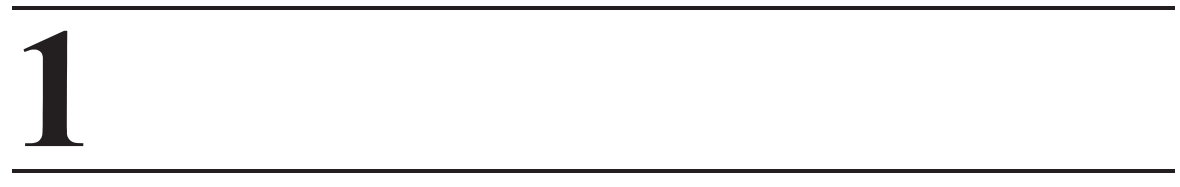

\title{
THE EVOLUTIONARY PHYLOGENY OF OOMYCETES - INSIGHTS GAINED FROM STUDIES OF HOLOCARPIC PARASITES OF ALGAE AND INVERTEBRATES
}

\section{GORDON W. BEAKES}

School of Biology, Newcastle University, Newcastle upon Tyne, United Kingdom

SAtoshi Sekimoto

Department of Botany, University of British Columbia, Vancouver, Canada

... phylogenetic speculations, valueless though these are considered to be....may stimulate studies in the life-history, cytology, morphology etc.... and clear the way for laying the foundations of a more logical system of classification.

- E. A. Bessey (1935), A Textbook of Mycology

\subsection{INTRODUCTION}

The unraveling of the evolutionary phylogeny of organisms has been given a tremendous impetus by the application of molecular techniques that have enabled biologists to, in effect, delve for phylogenetic clues in the DNA of organisms in a manner analogous to fossil hunters searching for physical evidence a century earlier. As pointed out by Bessey, a sound phylogenetic framework will hopefully inform and direct future exploration as well as provide a sound basis for classification. This is particularly pertinent in the era of bioinformatics, because this knowledge should help in choosing organisms that might be targeted for genome sequencing. The oomycetes are fungus-like heterotrophs that are saprophytes or parasites of diverse hosts in marine,

Oomycete Genetics and Genomics: Diversity, Interactions, and Research Tools Edited by Kurt Lamour and Sophien Kamoun Copyright (C) 2009 John Wiley \& Sons, Inc. 
freshwater, and terrestrial environments (Sparrow, 1960; Karling, 1981; Dick, 2001; Johnson et al., 2002). However, as a group, they are best known as devastating pathogens of plants.

Oomycetes are similar to the true fungi in that they produce complex branching, tip-growing, hyphal systems (forming mycelia) and have similar modes of nutrition and ecological roles (Richards et al., 2006). Summaries of the early speculations as to the likely evolutionary relationships of oomycetes to other organisms have been reviewed by Karling (1942), Dick (2001), and Johnson et al. (2002). Candidates cited as their likely ancestors have included amoebas, heterotrophic flagellates, diverse algal groups, and even chytrid fungi. However, most opinions tended to divide sharply between those, such as Scherffel, who considered oomycetes to have evolved from heterotrophic flagellates (Karling, 1942), and those like Bessey, who thought that photosynthetic algae were the more likely ancestors. In a seminal analysis, Bessey (1942) outlined two possible alternative evolutionary pathways within the oomycete lineage (Fig. 1.1a). In the first, it was suggested that oomycetes evolved from siphonaceous (coenocytic) algae and that they shared a common ancestor with the xanthophyte alga Vaucheria. The saprotrophic Saprolegniales were considered to be the most primitive order, which in turn gave rise to the Leptomitales, after which the lineage split and created the plant pathogenic Peronosporales along one branch and the holocarpic Lagenidiales along the other. The other scheme postulated that the most likely ancestor was an unknown "heterocont unicellular algae," which was ancestral to both the uniflagellate hyphochytrids and the biflagellate oomycetes. In this pathway, the holocarpic Olpidiopsidales were thought to be the most likely basal family and yielded the Lagenidiales. From these, the plant pathogenic Peronosporales diverged on one branch and the water moulds (Saprolegniales via the Leptomitales) on the other. In this review, we will summarize current views on the likely phylogeny and taxonomy of these organisms in the light of recent work that we have carried out on some of the less widely studied parasites of seaweeds, crustacea and nematodes.

\subsection{ANIMAL OR VEGETABLE - WHERE DO OOMYCETES BELONG ON THE TREE OF LIFE?}

The sequencing of conserved genes over the past two decades has led to a firm phylogenetic placement for most groups of living organisms. These studies have shown that the oomycetes are heterokonts (see Fig. 1.1b based on CavalierSmith and Chao, 2006; Tsui et al., 2008) within the chromalveolate "super kingdom" (Baldauf et al., 2000). The chromist section contains three, wholly or partially, photosynthetic lineages: the cryptomonads, haptophytes, and heterokonts, although the evidence for the inclusion of the former pair with the heterokonts is still not particularly strong (discussed by Harper et al., 2005). The alveolate section contains the parasitic apicocomplexa, phagotrophic ciliates, and mixotrophic dinoflagellates (Fig. 1.1b). The heterokonts/stramenopiles 


\section{Bessey scheme 1}

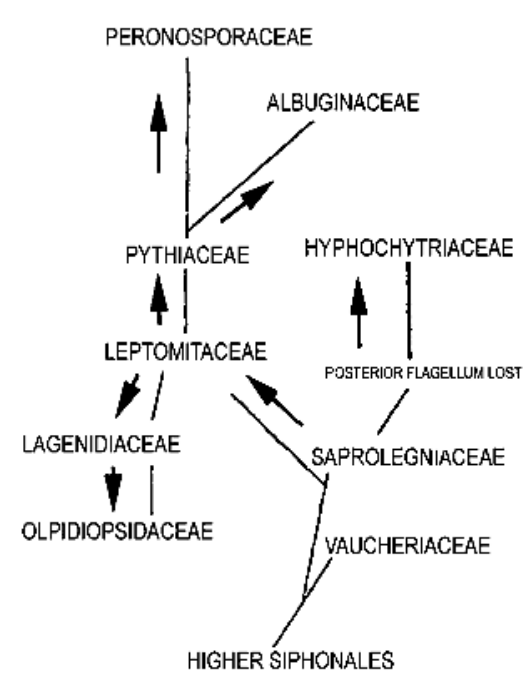

Bessey scheme 2

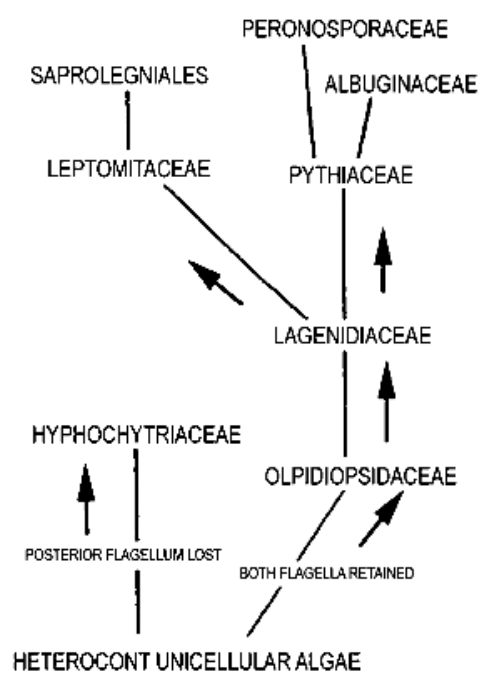

(a)

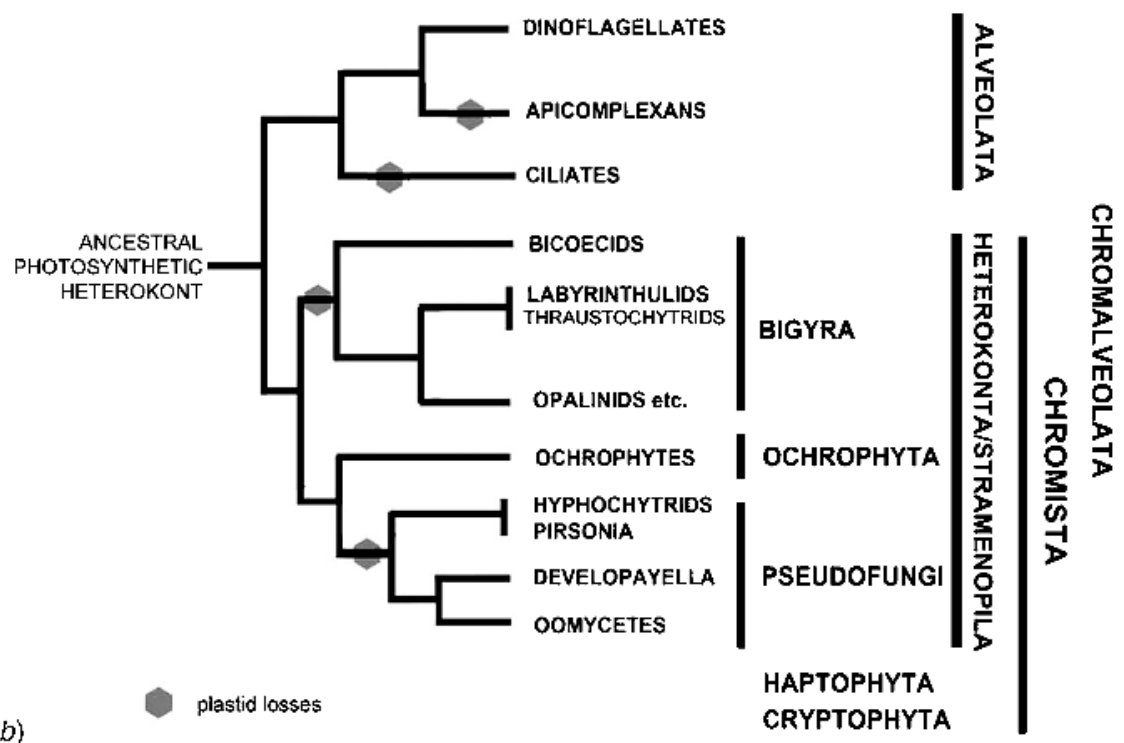

FIG. 1.1 Schematic summaries of the likely phylogenetic relationships of oomycetes and their relatives. (a) Schematic summary of two possible phylogenetic schemes showing the likely origins and family relationships within the oomycetes outlined by Bessey (1942). (b) Summary of the likely relationships between main classes and phyla within the Chromalveolata Superkingdom based on the terminology and information presented in Cavalier-Smith and Chao (2006) and Tsui et al. (2008). 
(Fig. 1.1b) are an extraordinarily diverse assemblage (Cavalier-Smith and Choa, 2006) that encompasses both autotrophic and heterotrophic organisms, including the chlorophyll c-containing algae (diatoms, chrysophytes, xanthophytes, phaeophytes, etc.), free-living bacteriotrophic flagellates (bicoecids, etc.), a group of absorptive gut commensals/parasites (opalanids, proteromonads, and Blastocystis), as well as the fungal-like osmotrophic representatives (labyrinthulids, hyphochytrids, oomycetes, etc.). Recent multigene analyses have indicated that the Rhizaria (a very diverse group, including filose amoeboid organisms and flagellates) are the sister group to the "Stramenopiles," which has led to this lineage being renamed as the SAR (Stramenopile/Alveolate/Rhizaria) clade (Burki et al., 2007).

The first published phylogenetic trees, which are mostly based on nuclearencoded ribosomal gene (SSU rDNA) sequences, showed that all the early branching heterokonts were nonphotosynthetic organisms, which suggested the late acquisition of plastids in the line (Leipe et al., 1996). Most recent evidence points to the whole chromalveolate lineage having developed from a common biflagellate (mastigonate) ancestor, which had acquired photosynthetic capabilities as a result of a single unique red algal enslavement (Patron et al., 2004; Harper et al., 2005; Cavalier-Smith and Chao, 2006). It is now thought that chloroplast loss has occurred many times within the lineage, including at least twice in the heterokont line (Fig. 1.1b; Cavalier-Smith and Chao, 2006; Tsui et al., 2008). Genomic data have also provided direct evidence for the photosynthetic ancestry of oomycetes with the discovery of vestigial plastid genes within the nuclear genome of Phytophthora (Lamour et al., 2007).

\subsection{KINGDOM WARS AND FAMILY TIES - A CASE OF CONFLICTING NOMENCLATURE}

There is still debate as to the correct (and taxonomically legal) kingdom/ phylum/class names to be used for the lineage that contains the oomycetes. Dick (2001) formally proposed (and diagnosed) the kingdom Straminipila for the heterokont lineage, pointing out the incorrect etymological derivation of the by then widely used informal term "Stramenopile," which was first introduced by Patterson (1989) in reference to the "straw-like" flagellum hairs (mastigonemes) possessed by most members of this group. However, in their attempt to bring order and consistency to the naming of protists, algae, and fungi, Adl et al. (2005) forcefully argued for the continued use of the name Stramenopile for this lineage, although they side stepped the issue of assigning hierarchical taxonomic ranks. Cavalier-Smith and Chao (2006) in their review of the phylogeny of phagotrophic heterokonts considered Dick's kingdom Straminipila to be synonymous with the kingdom Chromista erected by Cavalier-Smith (1981); this is the name that is used in many current nomenclatural databases.

Which phylum the oomycetes should be placed in has been no less controversial. The name Heterokonta has been used, respectively, to define 
both a "phylum" (Dick, 2001) and an "infrakingdom" (Cavalier-Smith and Chao, 2006). The Heterokonta infrakingdom was split into three phyla (see Fig. 1.1b), the Ochrophyta (encompassing all photosynthetic heterokonts), Bygyra (thraustochytrids, labyrinthulids, opalinids, etc.) and Pseudofungi (Cavalier-Smith and Chao, 2006). This includes, in addition to the oomycetes, the anteriorly uniflagellate hyphochytrids and associated sister clade, the flagellate parasitoid Pirsonia (Kühn et al., 2004), and the free-living bacteriotrophic marine zooflagellate Developayella. The latter species usually forms the sister clade to the oomycetes in small ribosomal subunit phylogenetic trees (Figs. 1b, 1.2a; Leipe et al., 1996). Patterson (1999) introduced yet another name, Sloomycetes, for a clade that contains all the osmotrophic fungal-like heterokonts. Perhaps because of the plethora of conflicting higher level taxonomic schemes, it is not surprising that many review volumes and textbooks continue to afford the oomycetes/oomycota their own phylum status.

The separation of the photosynthetic ochrophyte and heterotrophic oomycete lineages into two parallel clades derived from a common ancestor (Fig. 1.1b) is supported in the most recent phylogenetic trees (e.g., Cavalier-Smith and Chao, 2006; Tsui et al., 2008). This makes evolutionary sense as it explains the often reciprocal host-pathogen relationships observed between members of these two groups. For instance, both the hyphochytrid Anisopidium ectocarpi and the oomycete Eurychasma dicksonii are parasites of ectocarpalean phaeophyte algae (Küpper and Müller, 1999) and Pirsonia, Ectrogella, and Lagenisma all infect centric marine diatoms (Kühn et al., 2004; Schnepf et al., 1977, 1978; Raghu Kumar, 1980), which suggests the coevolution of parasitism between these two heterokont lineages (Cavalier-Smith and Chao, 2006). Environmental SSU rDNA sequences derived from small nanoplanktonic organisms sampled from diverse marine locations and ecosystems have shown that many of these lineages not only cluster within existing stramenopile clades, such as the hyphochytrids and oomycetes, but also form many "novel stremenopile" clades whose identities largely remain a mystery (Massana et al., 2004, 2006). The inclusion of such environmental sequence data in phylogenetic analyses significantly alters the topography of the heterokont tree and suggests that the Pirsonia/hyphochytrid clade may not be related as closely to the oomycetes as shown in Fig. 1.1b, although they undoubtedly share a common ancestor (Massana et al., 2004, 2006). It is to be expected that a systematic multigene approach to determining phylogeny in this lineage, as well as a significantly increased taxon sampling, will result in a much better understanding of the precise branching relationships of these various groups.

\subsection{THE NAME GAME - THE TAXONOMY OF "CROWN" OOMYCETES}

The current taxonomic organization of the oomycetes has largely been forged by two eminent scholars of zoosporic fungi, Frederick Sparrow (Sparrow, 1960, 
1976) and Michael Dick (Dick et al., 1984; Dick, 2001). In his encyclopedic treatise on aquatic fungi, Sparrow (1960) split the oomycetes into four orders, the Lagenidiales, Leptomitales, Peronosporales, and Saprolegniales. In his final synthesis, Sparrow (1976) suggested that all oomycetes could be assigned to one of two groups, which he informally termed "galaxies." Within the "saprolegnian galaxy," he placed the order Saprolegniales (in which he included the Leptomitaceae as a family) and introduced a new order the Eurychasmales, in which he placed many marine oomycete families. Within the "peronosporalean galaxy," he placed the Peronosporales (in which the Peronosporaceae, Pythiaceae, and Rhipidiaceae were included as families) and the holocarpic Lagenidiales.

Dick continued to refine oomycete classification culminating in his final synthesis, which he outlined in his magnum opus Straminipilous Fungi, in which he expanded the number of orders to around 12 (Dick, 2001). Sparrow (1976) had pointed out the inappropriateness of the name oomycete, which had been first introduced in 1879, and this was acted on by Dick $(1998,2001)$ who formally renamed the class the Peronosporomycetes. However, there has been a general reluctance to abandon the traditional name, and its retention does not apparently contravene the International Code of Nomenclature. Dick's major revision was substantially carried out before the advent of wide-ranging molecular studies and was based mostly on a scholarly reinterpretation of the available morphological and ecological data. The application of molecular methodologies has revolutionized understanding of the likely phylogenic relationships throughout biology, and it has become increasingly apparent that many of the more radical changes introduced by Dick (2001) are not supported by molecular data and will require revision.

For oomycetes, most molecular studies have used the sequences of either the nuclear-encoded SSU (Dick et al., 1999; Spencer et al., 2002), large ribosomal subunit (LSU) genes (Riethmüller et al., 1999, 2002; Petersen and Rosendahl, 2000; Leclerc et al., 2000) or associated internal spacer region (ITS) sequences (Cooke et al., 2000), or the mitochondrial-encoded cytochrome c oxidase subunit II (cox2) gene (Hudspeth et al., 2000; Cook et al., 2001; Thines et al., 2008). Phylogenetic sequence data for the oomycetes is still far from complete, and the current analyses should be viewed as work in progress. It is not possible, for instance, to assemble all species for which molecular data are available into a single all-encompassing tree. There are also significant gaps in data, particularly for many of the less economically important taxa and, particularly, for those holocarpic species that cannot be brought into laboratory culture.

The early molecular studies all supported both the monophyletic origins of the oomycetes (Riethmüller et al., 1999; Hudspeth et al., 2000; Petersen and Rosendahl, 2000) and the broad "galaxy split" proposed by Sparrow (1976), which were assigned formal subclass rank (Saprolegniomycetidae and Peronosporomycetidae) by Dick et al. (1999). However, it seems likely that these higher taxonomic ranks will also require major revision, particularly if the 
oomycetes are considered to be a phylum in their own right. The two main plant pathogenic orders, the Pythiales and Peronosporales, were also fairly well supported by sequence data (Cooke et al., 2000; Riethmüller et al., 2002; Hudspeth et al., 2003). Most analyses revealed the genus Phytophthora to be part of the Peronosporales rather than the Pythiales where it had traditionally been placed (Cooke et al., 2000; Riethmüller et al., 2002). Some larger genera of plant pathogenic oomycetes, such as Phytophthora (Cooke et al., 2000; Blair et al., 2008) and Pythium (Lévesque and de Cock, 2004), have been split into several clades, which ultimately may warrant at least genus-level separation. The K-clade of Pythium is phylogenetically interesting because it seems to form a clade that is intermediate between the Pythiales and Peronosporales orders as currently constituted (Lévesque and de Cock, 2004).

Another major surprise was the early divergence within this line of the white blister rusts (Albugo) and their clear separation from all other members of the Peronosporales (Fig. 1.2b; Petersen and Rosendahl, 2000; Hudspeth et al., 2003). They have now been placed in their own order, the Albuginales (Fig. 1.2b; Riethmüller et al., 2002; Voglmayr and Riethmüller, 2006). On the basis of their unusually long and unique COII amino acid sequence (derived from the cox 2 gene analysis), Hudspeth et al. (2003) considered them to be the earliest diverging clade in the Peronosporomycetidae, and they have been assigned their own subclass rank, which is called Albugomycetidae in some analyses (Thines et al., 2008).

The Rhipidiales are a small group of saprotrophic species associated with submerged twigs and fruit, most of which show restricted thallus development, consisting of a basal cell, holdfasts, and constricted (jointed) hyphal branches (Sparrow, 1960). They are a phylogenetically significant group that sits at the cusp of the saprolegnian-peronosporalean clade divergence (Figs. 1.2 and 1.3). Dick (2001) proposed that they be given their own order and subclass status (Rhipidiales, Rhipidiomycetidae), although he acknowledged the limited data on which this was based. Unfortunately, Sapromyces elongatus is still the only representative of this clade to have been sequenced and is a species whose placement has proven problematic (compare Fig. 1.2a and b). It has been reported as the basal clade to the Peronospomycetidae in cox2 trees (Hudspeth et al., 2000) and the basal clade to the Saprolegniomycetidae in LSU rDNA trees (Riethmüller et al., 1999; Petersen and Rosendahl, 2000). In our SSU rDNA trees (Fig. 1.2a), it forms part of a clade together with the holocarpic nematode parasite Chlamydomyzium, which diverges before both the major subclasses. However, the derived COII amino acid sequence showed that Sapromyces has the same signature amino acid insertion-deletion (indel) sequence $(\mathrm{LEF} / \mathrm{T})$ as that found in members of the Pythiales in contrast to the YTD indel sequence found in members of the Leptomitaceae (Hudspeth et al., 2000, 2003; Cook et al., 2001). Other members of the genus, such as C. oviparasiticum (Glockling and Beakes, 2006a), are diplanetic and have K-bodies in their zoospores (saprolegnian characteristics) but release their zoospores into a transient vesicle (a peronosporalean characteristic). Nakagiri 


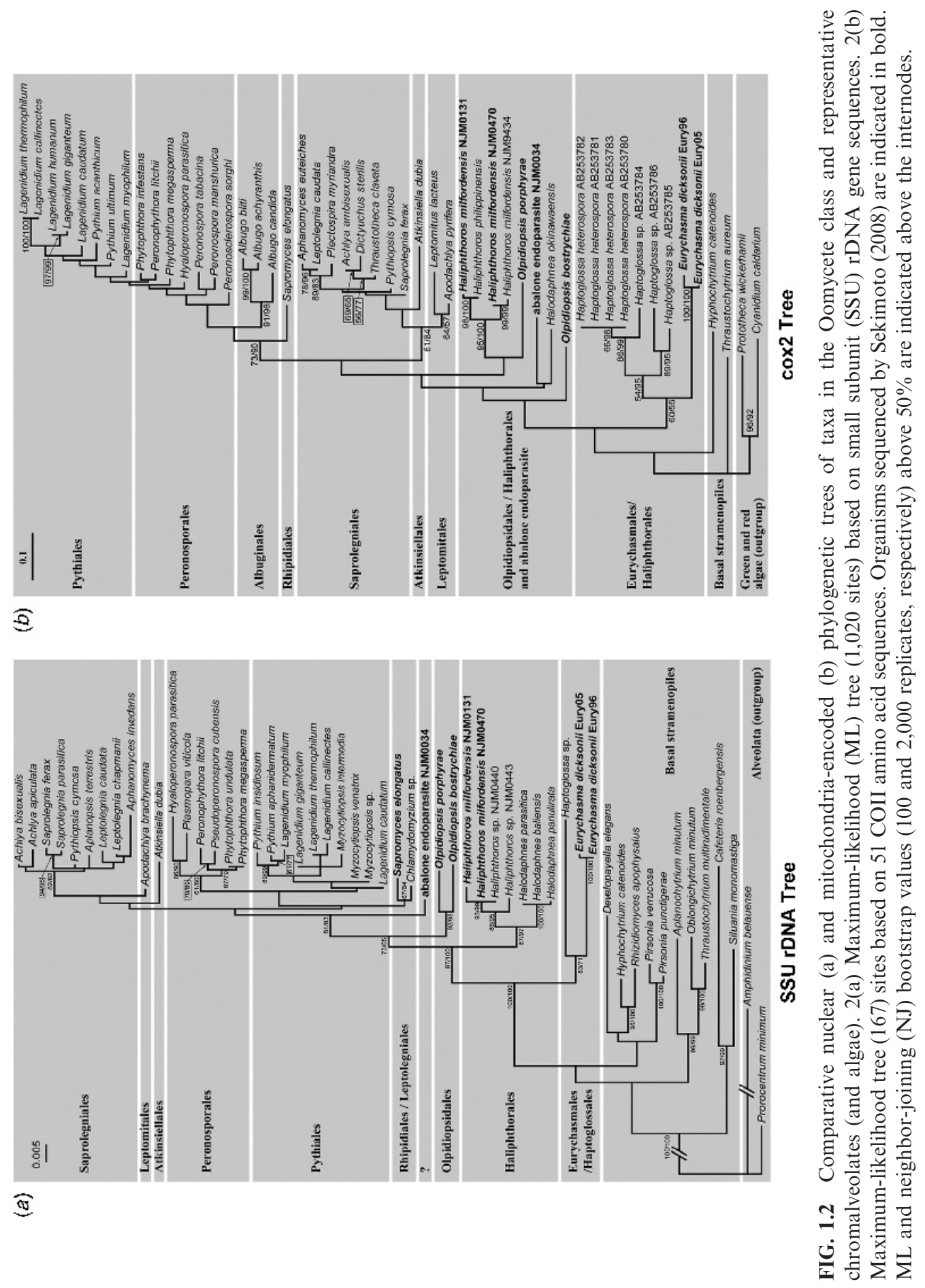


Predominantly fresinwater saprophytes plant \& animal debris

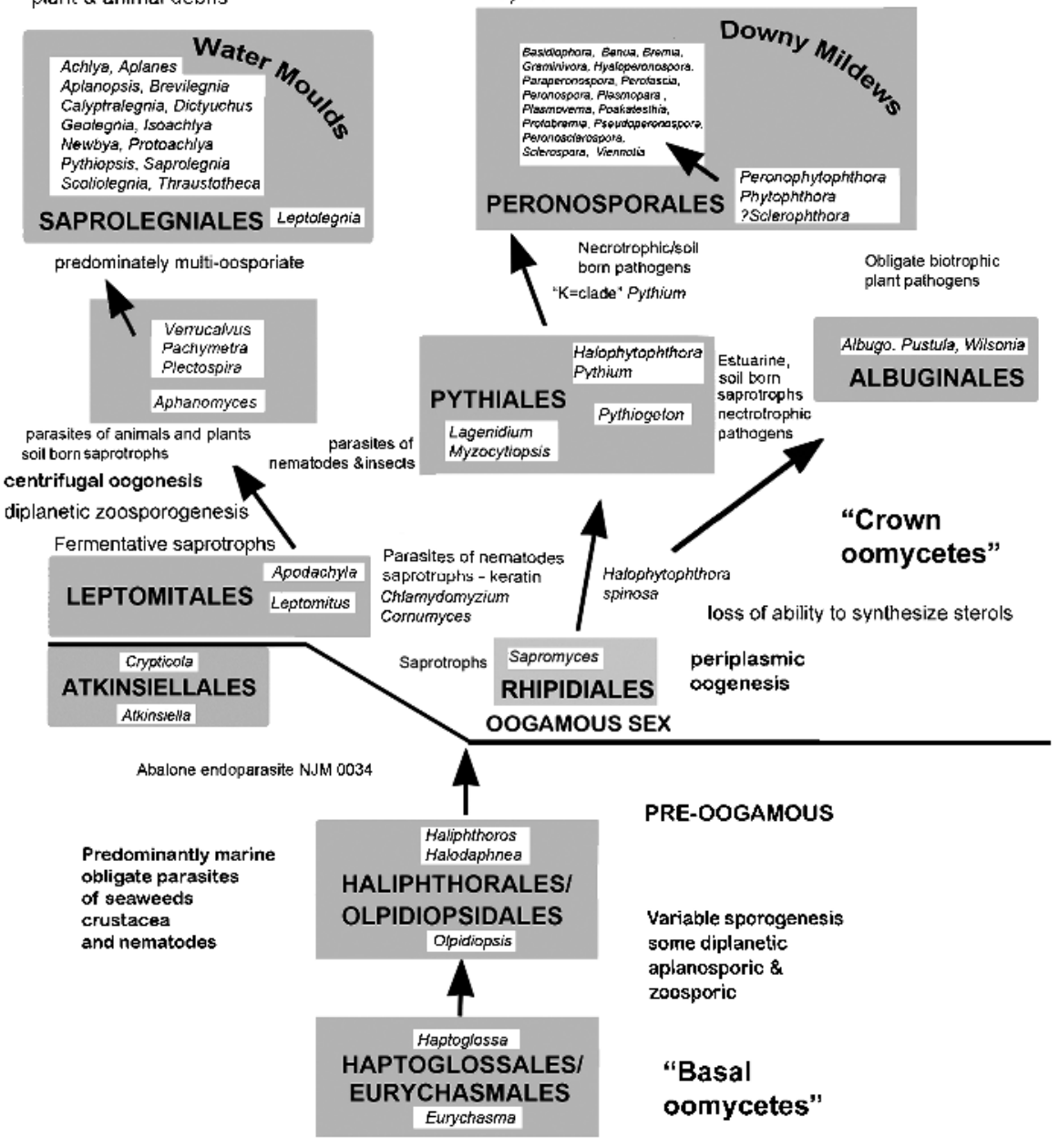

Obligate biotrophic pathogens mainly of aerial parts of plants

Necrotrophicisol

Obligate biotrophic

ia

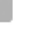


such as Aphanomycopsis, Brevilegniella, Leptolegniella, and the nematode parasite Nematophthora. Cornumyces was also tentatively included in this family by Dick (2001). Cornumyces isolates form a clade close to the Leptomitales at the base of the saprolegnian line (Inaba and Harayama, 2006) and also close to Chlamydomyzium when this species is included in the analyses (Inaba unpublished data). Unfortunately, no sequence data are available for any other of the genera in the Leptolegniellaceae. From the current, scant, molecular data, it seems that the clades located close to the point where the two main subclasses diverge (encompassing the Rhipidiales, Leptomitales, Atkinsiellales etc. Figs. 1.2 and 1.3) cannot be properly resolved until there has been far greater taxon and gene sampling.

\subsection{ALL AT SEA - THE EARLIEST DIVERGING OOMYCETE CLADES}

The first indication that some genera might fall outside the two main "crown" subclasses came from the study of Cook et al. (2001) who sequenced the cox 2 gene for several parasites of marine crustaceans. Two genera, Haliphthoros (Fig. 1.4p) and Halocrusticida (Fig. 1.4n and o), which has been reclassified as Halodaphnea by Dick, 1998, 2001), formed a well-supported clade that diverged before the main crown subclasses (Cook et al., 2001). However, another enigmatic marine crustacean parasite, Atkinsiella, formed a deeply branched clade basal to the Saprolegniomycetidae. This study indicated that these obscure marine genera might hold the key to understanding the evolutionary origins of the oomycetes as a whole. This conclusion was reinforced when it was reported that $E$. dicksonii, which is a holocarpic parasite of brown seaweeds (Fig. 1.4a and b), was found to be the earliest diverging member of the oomycete lineage (Küpper et al., 2006).

A range of marine parasites of seaweeds and invertebrates was selected for an integrated study into their molecular phylogeny, morphological development, and ultrastructural characteristics (Sekimoto, 2008; Sekimoto et al., 2007, 2008a-c). Phylogenetic trees based on the SSU rDNA (Fig. 1.2a) and cox2 genes (Fig. 1.2b) revealed that most of these marine holocarpic species fell into one of two deeply branched early diverging clades, which we have termed "basal oomycetes" (Fig. 1.3). The first clade in both SSU rDNA (Fig. 1.2a) and cox2 gene (Fig. 1.2b) trees encompassed two genera, Eurychasma and Haptoglossa (Beakes et al., 2006; Hakariya et al., 2007; Sekimoto et al., 2008b). These two genera have few apparent morphological and structural features in common (cf. Fig. 1.4a,b, f-1) and would never have been linked without molecular data. These two genera may merit their own order status, the Eurychasmales and Haptoglossales, although they do seem to form a distinct clade, albeit showing long branch separation (Fig. 1.2a and b). Eurychasma is an obligate parasite of filamentous brown seaweeds, mostly in the Ectocarpales (Fig. 1.4a and b), but it has a broad host range (Küpper and Müller, 1999). 
It will be interesting to determine whether the two as yet unsequenced enigmatic parasites of marine centric diatoms, Ectrogella (Raghu Kumar, 1980) and Lagenisma (Schnepf et al., 1977, 1978) also belong to this clade, as they also have a naked plasmodial infection stage.

Haptoglossa is an obligate parasite of rhabditid nematodes. Because of the apparent absence of mastigoneme hairs (Fig. 1.4f) and unique Plasmodiophora-like infection cells (Fig.1.4h-1; Beakes and Glockling, 1998), it was briefly considered to be related to the plasmodiophorids (Dick, 2001). Haptoglossa spp. show a remarkable and unsuspected diversity in their patterns of sporulation (Beakes and Glockling, 2002) and in the different types and micromorphology of the infection cells that are produced (Fig. 1.4h-1; Glockling and Beakes, 2000a and b, 2001, 2002). It seems to form an extremely diverse and deeply branching clade (Fig. 1.2b; Hakariya et al., 2007), which suggests that the Haptoglossaceae will undoubtedly require substantial taxonomic revision, employing both molecular sequencing and ultrastructural characterization.

The second basal clade (Fig. 1.2a and b) includes both parasites of red seaweeds (Fig.1.4c-e, m) and marine crustacea (Fig. 1.4n-p). The SSU rDNA tree suggests the two red seaweed parasites, Olpidiopsis porphyrae (Fig. 1.4c-e; Sekimoto et al., 2008a) and Olpidiopsis bostrychiae (Fig. 1.4m; Sekimoto, 2008; Sekimoto et al., 2009) form a separate clade from the crustacean parasites, Haliphthoros and Halodaphnea (syn. Halocrusticida) (Fig. 1.2a). However, in the cox 2 tree, the two groups cannot be resolved from each other (Fig. 1.2b). In the SSU tree, $O$. porphyrae and $O$. bostrychiae are separated by a significant branch length from each other, which in other oomycete families would warrant genus-level distinction. Haliphthoros also requires splitting into more taxa, because the sequenced isolates fell into two well-separated clades (Fig. 1.2b), which were not coincidental with the two currently recognized taxa Haliphthoros milfordensis and Haliphthoros phillipensis (Sekimoto et al., 2007). Because of their very different host ranges and morphological differences, we suggest that the Olpidiopsidales and Haliphthorales probably merit being retained in separate orders, but more sequence data are required before these can be unequivocally defined. We also predict, from their overall morphological and ultrastructural similarities, that these two early diverging clades are likely to encompass other marine genera such as Pontisma and Petersenia. Although somewhat similar in its host preferences and morphology, Atkinsiella dubia does not seem to be within the Haliphthorales and has been assigned to its own order, the Atkinsiellales, by Sekimoto (2008). Dick (1998) transferred Atkinsiella entomophaga, a parasite of dipteran larvae (Martin, 1977), to the genus Crypticola, which had been created for Crypticola clavulifera, an entomopathogenic species isolated from mosquito larvae (Frances et al., 1989). Interestingly, the latter does seem to form a clade with A. dubia in cox2 analyses (D. Hudspeth, unpublished data).

Environmental sequences obtained from unidentified marine nanoflagellates have revealed four well-separated "stramenopile" sequences (RA010613.4, 


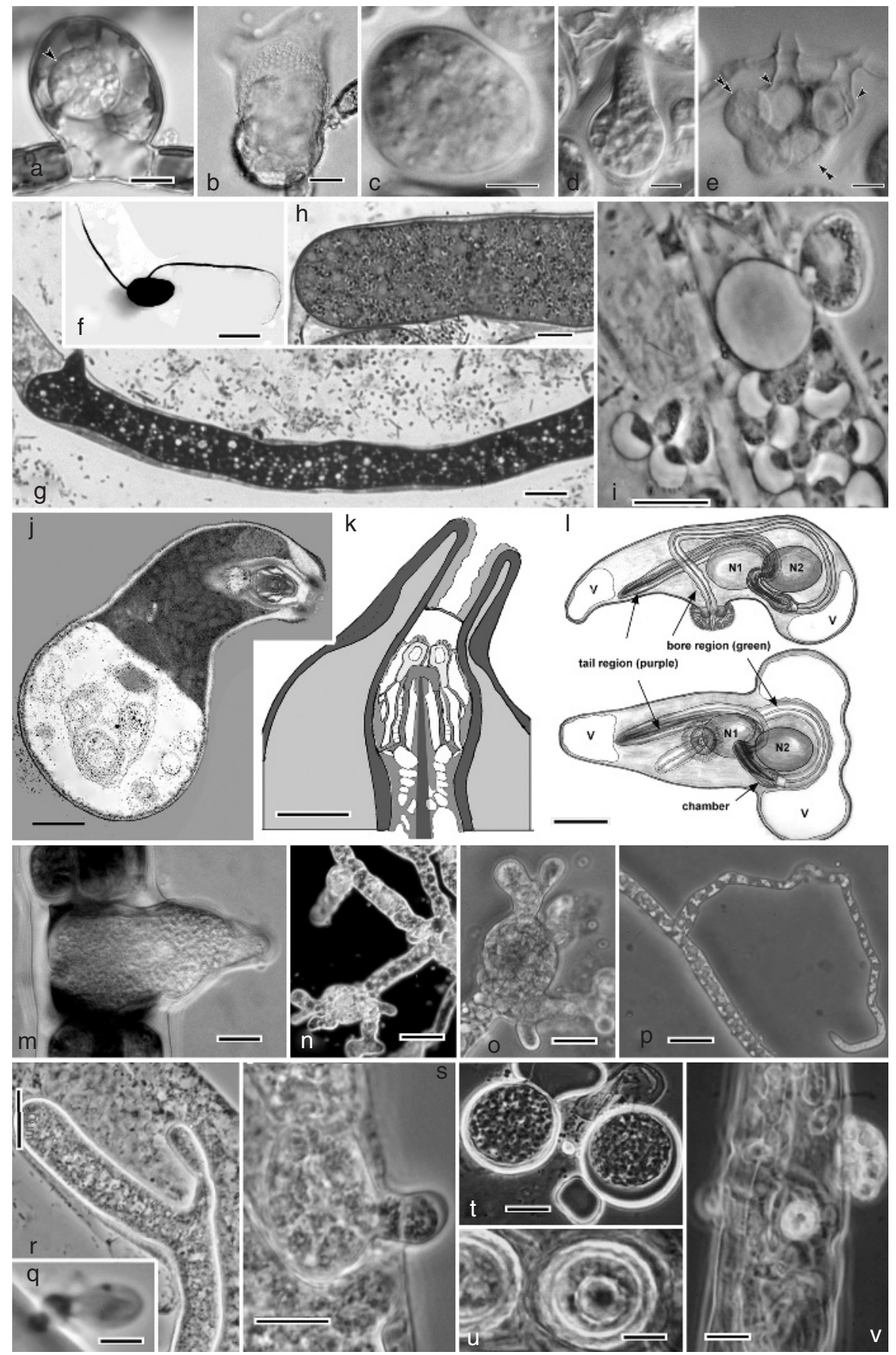


FIG. 1.4 (See color insert) (a-v) Light micrographs (LMs), electron micrographs (EMs), and diagrams summarizing some morphological and structural characteristics of basal holocarpic oomycetes. (a) Differential interference contrast (DIC) LM of a nonwalled (plasmodial) stage of Eurychasma thallus development, showing hugely swollen host cell. Bar $=10 \mu \mathrm{m}$. (b) DIC LM of a fully differentiated Eurychasma sporangium, showing net-like layer of peripheral cysts. Bar $=10 \mu \mathrm{m}$. (c) DIC LM of spherical thallus of Olpidiopsis porphyrae after the sporangial wall has formed, showing well-scattered nuclei. Bar $=5 \mu \mathrm{m}$. (d) DIC LM of an immature thallus of $O$. porphyrae, showing zoospore initials and tapered apical discharge tube. Bar $=5 \mu \mathrm{m}$. (e) DIC LM showing multiple infection of a single host cell with $O$. porphyrae thalli. Empty sporangia (single arrowheads) and young plasmodial stage thalli (double arrowheads) can be observed. Bar $=5 \mu \mathrm{m}$. (f -1$)$ Illustrations showing the morphological diversity shown by the nematode parasite Haptoglossa: (f) TEM wholemount of a zoospore of Haptoglossa dickii, showing smooth (nonmastigonate) anterior flagellum. Bar $=1 \mu \mathrm{m}$. (g) LM of a toluidine-blue-stained maturing thallus of Haptoglossa polymorpha, showing unbranched sausage-like thallus with a single terminal discharge tube, which has breached the nematode cuticle. Bar $=25 \mu \mathrm{m}$. (h) LM of a toluidine-blue-stained immature thallus of $H$. polymorpha, showing the dense nonvacuolated cytoplasm characteristic of this genus. Bar $=10 \mu \mathrm{m}$. (i) Phase contrast (PC) LM of mature thallus of $H$. heteromorpha, showing both large (upper) and small (lower) germinating aplanospores and showing typical tapering gun cell initials. Bar $=10 \mu \mathrm{m}$. (Courtesy of S. Glockling.) (j) Median TEM section of a gun cell of an unnamed Haptoglossa sp. Showing a basal vacuole and a recurved apex containing needle chamber. Bar $=1 \mu \mathrm{m}$. (k) Diagram showing a needle chamber at the apex of a mature gun cell of $H$. dickii and showing needle (dark purple) codes, investing cones (orange and green), and O-ring apparatus (yellow). Modified from Beakes and Glockling (1998). Bar $=0.5 \mu \mathrm{m}$. (1) Side and top LS views of small binucleate infection cell of $H$. heteromorpha [shown developing in (i) illustrating morphological diversity of such cells]. Color version of diagram available in Glockling and Beakes (2000b). Bar $=1 \mu \mathrm{m}$. (m) DIC LM of maturing thallus of Olpidiopsis bostrychiae infecting a single cell of filamentous red seaweed Bostrychia. Note the greatly expanded host cell and single apical discharge tube. Bar $=10 \mu \mathrm{m}$. (n-p) PC LM showing in vitro cultured thalli of the crustacean parasites Halodaphnea panulirata NJM9832 ( $\mathrm{n}$ and o) and Haliphthoros milfordensis NJM 0470 (p) Note the irregularly branching bulbous growth form of the former the compared with more hypha-like thalli and discharge tubes, which contain differentiating zoospore initials in the latter. (n) Bar $=25 \mu \mathrm{m}$, (o) Bar $=10 \mu \mathrm{m}$, (p) Bar $=25 \mu \mathrm{m}$. (q, t) PC LM of a germinating cyst and branched tubular thallus of nematode parasite Chlamydomyzium dictyuchoides. Note the small appressorial-like pad produced by the germinating spore at the point of presentation (q) and rather frothy cytoplasm (r) (q) Bar $=5 \mu \mathrm{m}(\mathrm{t}) \mathrm{Bar}=20$ $\mu \mathrm{m}$. Courtesy of S. Glockling. (S) PC LM of mature sporangium of nematode parasite Myzocytiopsis vermicola, showing a small segmented thalli that contains fully differentiated zoospores and a discharge tube, with apical papillar plug, which forms an evanescent restraining vesicle around escaping zoospores. Bar $=10 \mu \mathrm{m} .(\mathrm{t}, \mathrm{u})$ PC LM of immature oospheres and adjacent antheridia (t) and fully mature oospores (u) of $M$. vermicola. Bar $=5 \mu \mathrm{m}$. Color versions are available from Glockling and Beakes (2006b). (v) PC LM of a mature thallus of the Myzocytiopsis intermedia showing hyphallike thalli and external vesicles containing refractile clusters of differentiating zoospores. Bar $=10 \mu \mathrm{m}$. Courtesy of S. Glockling. 
BL010320.2, BOLA320, CCW73) all located on the SSU rDNA tree between E. dicksonii and the crown oomycete clade (Massana et al., 2004, 2006). When included with the sequence data described here, these environmental sequences did not cluster within either of the two basal clades outlined above but formed two more novel clades between the Haliphthoros/Halodaphnea clade and the crown oomycetes (Sekimoto, 2008). This suggests that basal marine oomycetes are both more widespread and diverse than currently appreciated, and a concerted effort should be made to try and isolate, identify, and sequence as many of these taxa as possible.

\subsection{ODD FELLOWS - WHERE DO THE LAGENIDIACEOUS NEMATODE PATHOGENS FIT IN?}

The only holocarpic lagenidiaceous species that was included in early phylogenetic studies was the mosquito parasite Lagenidium giganteum, which was unambiguously shown to be within the Pythium clade (Dick et al., 1999; Petersen and Rosendahl, 2000; Hudspeth et al., 2000). Unfortunately, Dick (2001) argued that this species was the only valid representative of this longestablished genus and proceeded to redistribute most of the other Lagenidium species among many newly created orders. He transferred the nematode parasites to the Myzocytiopsidales and the marine lagenidiaceous species to the Salilagenidiales, both of which he placed in the Saprolegniomycetidae. However, almost concurrently, Cook et al. (2001) reported that three marine lagenidiaceous parasites of crustacea were part of the same clade as L. giganteum and some Pythium species, which confirmed that both marine and terrestrial "lagenidiaceous" species were closely related as originally thought. Most nematode infecting Myzocytiopsis species (Fig. 1.4s-v) also seem to be closely related to Lagenidium spp. (Fig. 2a; Beakes et al., 2006), which suggests the Lagenidiaceae could form a discrete family within the Pythiales. The boundary among the genera Lagenidium, Pythium, and Myzocytium had always been ill-defined (discussed at length by Dick, 2001) and still requires additional gene and taxon sampling before this group can be properly resolved. It will be interesting to observe how these taxa relate to the various Pythium clades recently identified by Lévesque and De Cock (2004). There is no support for the orders Salilagenidiales and Myzocytiopsidales created by Dick (1998, 2001), and both should be rejected.

\subsection{A PLACE FOR THE WATER MOLDS - A FISHY TALE}

All genera in the water mold order the Saprolegniales form a well-defined clade (Dick et al., 1999; Riethmüller et al., 1999; Petersen and Rosendahl, 2000; Leclerc et al., 2000; Inaba and Tokumasu, 2002; Spencer et al., 2002). On the basis of their study, Dick et al. (1999) proposed creating a new family within 
the Saprolegniales called the Leptolegniaceae, in which he subsequently placed the genus Aphanomyces (Dick, 2001). This was almost certainly a premature decision, because in the LSU rDNA analysis of Petersen and Rosendahl (2000), Aphanomyces was found to form the first diverging clade in the Saprolegniales, whereas Leptolegnia continued to be associated with other genera of the saprotrophic water moulds.

Aphanomyces is a genus that includes many important pathogens of crustacea (e.g., Aphanomyces astaci; Dykstra et al., 1986), fish (e.g., Aphanomyces invadans; Lilley et al., 2003), and plant roots (e.g., A. euteiches; Johnson et al., 2002), which together with several genera of little studied soil/root inhabiting oomycetes, Plectospira, Pachymetra (Reithmüller et al., 1999), and Verrucalvus (Thines unpublished data) form a well-supported clade that is separate from other members of the Saprolegniaceae (Fig. 1.3). These genera, together with the unsequenced Verrucalvus, will probably merit their own as yet undescribed order (Fig. 1.3). Dick et al. (1984) had placed Pachymetra together with Verrucalvus in their own family called the Verrucalvaceae, which were then included with the graminocolous downy mildews in the order Sclerosporales. As a result, Dick et al. (1984) removed this group of well-known plant pathogens from the "peronosporalean line" to the Saprolegniales (Dick, 2001). However, recent molecular studies have shown that all the leaf-infecting genera of graminocolous downy mildews (e.g., Peronosclerospora, Sclerospora, etc.) are scattered among other downy mildew genera in the Peronosporales (Hudspeth et al., 2003; Göker et al., 2007; Thines et al., 2008). These graminaceous pathogens do belong to the Peronosporales, but there is no molecular support for retaining the Sclerosporales as a separate order or family.

Although the family Saprolegniaceae contains mostly saprotrophic species, some water molds are important pathogens of fish (e.g., Saprolegnia parasitica, Dieguez-Uribeondo et al., 2007). The first phylogenetic analysis that attempted to map traditional spore-release characters, which had been used to define genera in the water molds (Saprolegniaceae), was reported by Daugherty et al. (1998) using ITS sequence data. The familiar water mold genus Saprolegnia, which releases motile primary zoospores, seemed to form a separate clade from those genera, Achlya, Thraustotheca, and Dictyuchus, where the motile primary zoospore phase had been lost. However, this study was based on just a single sequence from each taxon, and it quickly became apparent that this was far too simplistic an overview of the Saprolegniaceae. When greater numbers of taxa were included in the phylogenetic analyses, it became apparent that the two largest and most familiar water mold genera Achlya and Saprolegnia did not form monophyletic taxa but had representatives scattered in several different "genus-level" clades (Leclerc et al., 2000; Inaba and Tokumasu, 2002, Spencer et al., 2002). It is now clear that the traditional generic classification of the Saprolegniaceae based on the pattern of zoospore discharge does not accurately reflect the underlying phylogenetic relationships in this family (Riethmüller et al., 1999; Inaba and Tokumasu, 2002; Spencer et al., 2002). Even in such a well-known genus as Saprolegnia, the application of molecular methods has 
proved problematic because many currently recognized taxa seem to be polyphyletic on ITS trees (Hulvey et al., 2007). A reclassification of the familiar water molds based on combined molecular and morphological characters is urgently required.

\subsection{WHAT DOES IT ALL MEAN? EVOLUTIONARY PERSPECTIVES AND SPECULATIONS}

The phylogenetic trees (Fig. 1.2a and b) clearly show that the earliest diverging oomycete genera are predominantly marine organisms. Even Haptoglossa, which is the only terrestrial genus in the "basal oomycete" assemblage, has been reported as a parasite of marine nematodes (Newell et al., 1977). This evidence is contrary to Dick's (2001) view that "all existing evidence points to a freshwater or terrestrial origin for the straminipilous fungi." Although "crown oomycetes" (see Fig. 1.3) are predominantly freshwater (the saprolegnian lineage) or terrestrial (the peronosporalean lineage), there are nevertheless a minority of marine representatives scattered throughout both lines. Some Aphanomyces sp. and many other genera of Saprolegniaceae have been isolated from estuarine ecosystems and can tolerate high or fluctuating salinities (Dykstra et al., 1986; Padgett, 1978). The Pythiales include many marine representatives, which include several Lagenidium (e.g., Lagenidium callinectes) and Pythium spp. (e.g., Pythium porphyrae and Pythium grandisporangium). Both Myzocytiopsis vermicola and Gonimochaete latitubus have been isolated from littoral marine nematodes (Newell et al., 1977). These observations suggest the intriguing possibility that the oomycetes may have migrated from the sea to the land (soil) along with their nematode hosts. Rhabditid nematodes are known from marine, estuarine, and terrestrial habitats (De Ley, 2006), which supports such a hypothesis. Host switching between soil-born nematodes and plants roots may have occurred at least twice, in Aphanomyces and in the Pythiales line. The exclusively marine genus Halophytophthora, which has papillate Phytophthora-like sporangia, forms a polyphyletic assemblage distributed among Pythium and Phytophthora species (Cooke et al., 2000; Nakagiri, 2002; Lévesque, unpublished data). It had been assumed that Halophytophthora had reacclimatized to the marine/estuarine environment (i.e., they were the oomycete equivalent of whales), but it is possible that they could represent vestiges of the original marine line (Nakagiri, 2002). If oomycetes had their origins in the open sea, it is in the estuarine benthic environments where they probably made the transition to becoming terrestrial saprotrophs and plant pathogens.

Recently, genomic studies have revealed that lateral gene transfer has occurred between the oomycetes and true fungi (Richards et al., 2006). It has even been suggested that their fungal-like growth form might have been acquired as a result of this. However, a complete morphological spectrum from simple spherical to ovoid thalli (Fig. 1.4a,c,d, and m), through unbranched sausage-like 
thalli (Fig. 1.4 g and $\mathrm{h}$ ) to segmented branched thalli (Fig. 1.4r and s) and typical fine hyphal-like thalli (Fig. 1.4r), can all be found among these early diverging holocarpic parasites. It suggests that the fungus-like growth pattern may have evolved without the need to invoke gene transfer from true fungi. However, the body cavities of nematodes or invaded plant tissues may have provided suitable "closed environments," whereby true fungi and oomycetes could have come into close contact and exchanged genetic material.

All basal clade taxa (Fig. 1.2a and b) studied to date apparently lack sexual stages. Sparrow (1976) remarked that it seemed improbable that all marine oomycete genera could be genuinely asexual or "choose to live monastically" as he quaintly put it. He speculated that they probably had some form of nonoogamous sexual cycle. The best evidence in support of this comes from Lagenisma coscinodisci, which produces zoomeiospores that form sexual cysts that conjugate to form the zygote (Schnepf et al., 1977). Many Haptoglossa species produce both uninucleate and binucleate infection cells (Fig. 1.41; Beakes and Glockling, 2000b, 2001, 2002), but we have no idea of how these fit into their overall life cycle. As the genes specifically associated with sexual reproduction in oomycetes are identified (e.g., Prakob and Judelson, 2007), it will be interesting to explore whether and where they may be expressed in these basal species. Oogamous sexual reproduction is clearly one of the major evolutionary developments that define crown oomycetes. Only the genus Olpidiopsis among those in the basal clades is reported to form oogonia and only then in freshwater species that parasitize water molds (Sparrow, 1960). The holocarpic differentiation of neighboring thallus compartments into antheridia and oogonia observed in the genus Myzocytiopsis (Fig.1.4t and $\mathrm{u}$; Glockling and Beakes, 2006b) illustrates how oogamous reproduction probably evolved. The unioosporiate condition is clearly the most primitive form because it is prevalent in all orders except for the Saprolegniales (Fig. 1.3).

Another inescapable inference from the phylogenetic trees (Fig. 1.2) is that oomycetes have been "hard wired" for parasitism since their inception. Both basal-clade genera Eurychasma and Haptoglossa are obligate parasites, which cannot be cultured independently from their hosts. E. dicksonii is a wide-ranging parasite of phaeophyte seaweeds (Küpper et al., 1999). Related species are reported to infect both red and green seaweed hosts (Karling, 1981), which indicates that these may be fairly broad-spectrum parasites. At least one other major phylum, which is the apicocomplexa within the Chromalveolate lineage, is exclusively parasitic. Like many basal oomycetes, these are parasites of many invertebrate phyla, such as mollusks and arthropods, but they also infect all classes of vertebrates as well (Marquardt and Speer, 2001). Recent genomic analysis has revealed many significant similarities at the molecular level between parasitism in apicocomplexans and oomycetes (Robold and Hardham, 2005; Torto-Alalibo et al., 2005; Bhattacharjee et al., 2006; Talbot, 2007). These similarities are reinforced when one considers that the initial stages of thallus development in all basal oomycete parasites of marine algae are as unwalled 
plasmodia (Fig. 1.4a and c) located within a membrane-bound host vacuole (Eurychasma, Olpidiopsis; Sekimoto et al., 2008a-c; Ectrogella; Raghu Kumar, 1980; Lagenisma, Schnepf et al., 1978; Petersenia, Pueschel and van der Meer, 1985), which is equivalent to the parasitophorous vacuole of apicocomplexans (see Talbot, 2007). The flagellate parasitoid Pirsonia infects diatoms by means of an invasive pseudopodium that forms a "feeding" trophosome adjacent to the host protoplast, which it ingests by phagocytosis rather than by absorption (Schnepf and Schweikert, 1997). A Pirsonia-like parasitoid might have been the kind of organism that was ancestral to the oomycetes. It will certainly be interesting to find out more about the unknown novel stramenopile clades that have been shown to diverge just before the oomycetes (Massana et al., 2004, 2006). Many fundamental mechanisms associated with both infection (attachment to host) and host-parasite interaction (effector-protein delivery systems) are deeply embedded within the lineage and may have been present in the original flagellate root ancestor to all chromalveolates (Fig. 1.1b) perhaps even before the primary plastid acquisition event. Some present-day dinoflagellates are parasites of other chromalveolates and crustacea (Coats, 1999) and show that both parasitic and autotrophic lifestyles can coexist.

These molecular phylogenetic studies on holocarpic parasites of algae and invertebrates have provided a much clearer overview of the likely evolutionary and taxonomic relationships within the oomycetes, which we have summarized diagrammatically in Fig. 1.3. The scheme proposed by Bessey nearly 70 years ago (Fig. 1.1a), which suggested that the oomycetes evolved from a photosynthetic heterokont alga and that the holocarpic Olpidiopsidales and Lagenidiales were at the root of the lineage, has been shown using modern molecular methodologies to have been remarkably perceptive.

\section{ACKNOWLEDGMENTS}

We would like to acknowledge the sharing of phylogenetic information and/or helpful contributions made to our discussions by many of our colleagues who work on oomycete fungi, particularly Claire Gachon, Sally Glockling, Marcus Göker, Masateru Hakariya, Kishio Hatai, Shigeki Inaba, Frithjof Küpper, Andre Lévesque, Akira Nagakiri, Marco Thines, and Hermann Voglmayr. Our special thanks are extended to Daiske Honda, who mentored and guided the work on the marine parasites that formed part of the doctoral thesis of S. S.

\section{REFERENCES}

Adl SM, Simpson AG, Farmer MA, Anderson RA, Anderson OR, Barta SR, Bowser

SS, Brogeroile G, Fensome RA, Fredericq S et al. 2005. The new higher level classification of the eukaryotes with emphasis on the taxonomy of protists. J Eukaryot Microbiol 52:399-451. 
Baldauf SL, Roger AJ, Wenk-Siefert I, Doolittle WF 2000. A kingdom-level phylogeny of eukaryotes based on combined protein data. Science 290:972-977.

Beakes GW 1981. Ultrastructural aspects of oospore differentiation. In: Hohl H, Turian, $G$ editors. The fungal spore: morphogenetic controls. Academic Press. New York. pp. 71-94.

Beakes GW 1987. Oomycete phylogeny: ultrastructural perspectives. In: Rayner ADM, Brasier CM, Moore D editors. Evolutionary biology of the fungi. Cambridge University Press, Cambridge, UK, pp. 405-421.

Beakes GW 1989. Oomycete fungi: their phylogeny and relationship to chromophyte algae. In: Green JP, Leadbeater BSC, Diver WL editors. The chromophyte algae: problems and perspectives. Clarendon Press, Oxford, UK, pp. 325-342.

Beakes GW, Glockling SL 1998. Injection tube differentiation in gun cells of a Haptoglossa species which infects nematodes. Fungal Genet Biol 24:45-68.

Beakes GW, Glockling SL 2000. An ultrastructural analysis of organelle arrangement during gun (infection) cell differentiation in the nematode parasite Haptoglossa dickii. Mycol Res 104:1258-1269.

Beakes GW, Glockling SL 2002. A comparative fine-structural study of dimorphic infection cells in the nematophagous parasite, Haptoglossa erumpens. Fungal Genet Biol 37:250-262.

Beakes GW, Glockling SL, James TY 2006. The diversity of oomycete pathogens of nematodes and its implications to our understanding of oomycete phylogeny. In: Meyer W, Pearce C editors. Proc. Eighth Interntl Mycol Cong. Medimond, Italy, pp. 7-12.

Bessey EA 1935. A textbook of mycology. P. Blakiston’s Son \& Co. Philadephia, PA.

Bessey EA 1942. Some problems in fungus phylogeny. Mycologia 34:355-379.

Bhattacharjee S, Hiller NL, Konstantinos L, Win J, Thirumala-Devi K, Young C, Kamoun S, Haldar K 2006. The malarial host-targeting signal is conserved in the Irish Potato famine pathogen. PLoS Path 2: e50.

Blair JE, Coffey MD, Park S-Y, Geiser DM, Kang S 2008. A multi-locus phylogeny for Phytophthora utilizing markers derived from complete genome sequences. Fungal Genet Biol 45:266-277.

Burki F, Shalchian-Tabrizi K, Minge M, Skjaeveland A, Nikolaev SI, Jakobsen KS, Pawlowski J 2007. Phylogenetics reshuffles the eukaryote supergroups. PLoS2: e790.

Cavalier-Smith T 1981. Eukaryote kingdoms: seven or nine? Biosystems 14:461-481.

Cavalier-Smith T, Chao EEY 2006. Phylogeny and megasystematics of phagotrophic heterokonts (Kingdom Chromista). J Mol Evol 62:388-420.

Coats DW 1999. Parasitic life styles of marine dinoflagellates. J Eukaryot Microbiol 46:402-409.

Cook KL, Hudspeth DSS, Hudspeth MES 2001. A cox2 phylogeny of representative marine peronosporomycetes (Oomycetes). Nova Hedwiga Beiheft 122:231-243.

Cooke DEL, Drenth A, Duncan JM, Wagels G, Brasier CM 2000. A molecular phylogeny of Phytophthora and related oomycetes. Fungal Genet Microbiol 30:17-32.

Daugherty J, Evans TM, Skillom T, Watson LE, Money NP 1998. Evolution of spore release mechanism in the Saprolegniaceae (Oomycetes): evidence form a phylogenetic analysis of internal transcribed spacer sequences. Fungal Genetic Microbiol 24:354-363. 
De Ley P 2006. A quick tour of nematode diversity and the backbone of nematode phylogeny. WormBook http://wormbook.org.

Dick MW 1998. The species and systematic position of Crypticola in the Peronosporomycetes, and a new names for Halocrusticida and species therein. Mycol Res 102:1062-1066.

Dick MW 2001. Straminipilous fungi. Kluwer, Dordrecht, Germany.

Dick MW, Vick MC, Gibbings JG, Hedderson TA, Lopez Lastra CC 1999. 18S rDNA for species of Leptolegnia and other Peronosporomycetes: justification of the subclass taxa Saprolegniomycetidae and Peronosporomycetidae and division of the Saprolegniaceae sensu lato into the Leptolegniaceae and Saprolegniaceae. Mycol Res 103:1119-1125.

Dick MW, Wong PTW, Clark G 1984. The identity of the oomycete causing 'Kikuyu Yellow, with a reclassification of the downy mildews. Bot J Linn Soc 89:171-197.

Dieguez-Uribeondo J, Fregeneda-Grandes JM, Cerenius L, Perez-Iniesta M, Aller-Gancedo JM, Tellerı MT, Soderhall K, Martına MP 2007. Re-evaluation of the enigmatic species complex Saprolegnia diclina-Saprolegnia parasitica based on morphological, physiological and molecular data. Funal Genet Biol 44: 585-601.

Dykstra DP, Noga EJ, Levine JF, Moye DE 1986. Characterization of the Aphanomyces species associated with ulcerative mycosis (UM) in menhaden. Mycologia 78:664-672.

Frances SP, Sweeney AW, Humber RA 1989. Crypticola clavulifera gen. et. sp. nov. and Lagenidium giganteum: oomycetes pathogenic for dipterans infesting leaf axils in an Australian rain forest. J Invertebr Pathol 54:103-111.

Glockling SL, Beakes GW 2000a. Two new Haptoglossa species (H. erumpens and $H$. dickii) infecting nematodes in cow manure. Mycol Res 104:100-106.

Glockling SL, Beakes GW 2000b. The ultrastructure of the dimorphic infection cells of Haptoglossa heteromorpha illustrates the developmental plasticity of infection apparatus structures in a nematode parasite. Can J Bot 78:1095-1107.

Glockling SL, Beakes GW 2001. Two new species of Haptoglossa from N.E. England, H. northumbrica and H. polymorpha. Bot J Linn Soc 136:329-338.

Glockling SL, Beakes GW 2002. Ultrastructural morphogenesis of dimorphic arcuate infection (gun) cells of Haptoglossa erumpen, an obligate parasite of Bunonema nematodes. Fungal Genet Biol 37:250-262.

Glockling SL, Beakes GW 2006a. Structural and developmental studies of Chlamydomyzium oviparasiticum from Rhabditis nematodes and in culture. Mycol Res 110:1119-1126.

Glockling SL, Beakes GW 2006b. An ultrastructural study of development and reproduction in the nematode parasite Myzocytiopsis vermicola. Mycologia 98:7-21.

Göker M, Voglmayr H, Riethmüller A, Oberwinkler F. 2007. How do obligate parasites evolve? A multi-gene phylogenetic analysis of downy mildews. Fungal Genet Biol 44:105-122.

Göker M, Voglmayr H, Riethmüller A, Weiss M, Oberwinkler, F 2003. Taxonomic aspects of Peronosporaceae inferred from Bayesian molecular phylogenetics. Can J Bot 81:672-683. 
Hakariya M, Hirose D, Tokumasu S 2007. A molecular phylogeny of Haptoglossa species, terrestrial peronosporomycetes (oomycetes) endoparasitic on nematodes. Mycoscience 48:169-175.

Hakariya M, Masuyama N, Saikawa M 2002. Shooting of sporidium by "gun" cells in Haptoglossa heterospora and H. zoospora and secondary zoospore formation in H. zoospora. Mycoscience 43:119-125.

Harper JT, Waanders E, Keeling PJ 2005. On the monophyly of chromalveolates using a six-protein phylogeny of eukaryotes. Intl J Syst Evol Microbiol 55:487-496.

Hudspeth DSS, Nadler SA, Hudspeth MES 2000. A cox II molecular phylogeny of the Peronosporomycetes. Mycologia 92:674-684.

Hudspeth DSS, Stenger D, Hudspeth MES. 2003. A cox2 phylogenetic hyphothesis for the downy mildews and white rusts. Fungal Divers 13:47-57.

Hulvey JP, Padgett DE, Bailey JC 2007. Species boundaries within the Saprolegnia (Saprolegniales, Oomycota) based on morphological and DNA sequence data. Mycologia 99:421-429.

Inaba S, Hariyama S 2006. The phylogenetic studies on the genus Cornumyces (Oomycetes) based on the nucleotide sequences of the nuclear large subunit ribosomal RNA and the mitochondrially encoded cox2 genes. 8th Int. Mycol Cong. Handbook and Abstracts. p. 330.

Inaba S, Tokumasu S 2002. Phylogenetic relationships between the genus Saprolegnia and related genera inferred from ITS sequences. Abstracts 7th Int. Mycol Cong. Oslo. 687 p. 208.

Johnson TW, Seymour RL, Padgett DE 2002. Biology and systematics of the Saprolegniaceae. http://dl.uncw.edu/digilib/biology/fungi/taxonomy $\% 20$ and $\% 20$ systematics/ padgett $\% 20$ book/ accessed April 2008.

Karling JS 1942. The simple holocarpic biflagellate phycomycetes. Columbia University Press, New York.

Karling JS 1981. Predominantly holocarpic and eucarpic simple biflagellate phycomycetes. J Cramer Vaduz.

Kühn SF, Medlin LK, Eller G 2004. Phylogenetic position of the parasitoid nanoflagellate Pirsonia inferred from nuclear-encoded small subunit ribosomal DNA and a description of Pseudopirsonia n. gen. and Pseudopirsonia mucosa (Drebes) comb. nov. Protist 155:143-156.

Küpper FC, Maier I, Müller DG, Loiseaux-de Goer S, Guillou L 2006. Phylogenetic affinities of two eukaryotic pathogens of marine macroalgae, Eurychasma dicksonii (Wright) Magnus and Chytridium polysiphoniae Cohn. Cryptogam Algol 27:165-184.

Küpper FC, Müller DG 1999. Massive occurrence of the heterokont and fungal parasites Anisolpidium, Eurychasma and Chytridium in Pylaiella litoralis (Ectocarpales, Phaeophyceae). Nova Hedwig 69:381-389.

Lamour KH, Win J, Kamoun S 2007. Oomycete genomics: new insights and future directions. FEMS Microbiol Lett 274:1-8.

Leclerc MC, Guillot J, Deville M 2000. Taxonomic and phylogenetic analysis of Saprolegniaceae (Oomycetes) inferred from LSU rDNA and ITS sequence comparisons. Anton Van Leeuk 77:369-377. 
Leipe DD, Tong SM, Goggin CL, Slemenda SB, Pieniazek NJ, Sogin ML 1996. 16S-like rDNA sequences from Developayella elegans, Labyrinthuloides haliotidis, and Proteromonas lacertae confirm that the stramenopiles are a primarily heterotrophic group. Eur J Protist 33:369-377.

Lévesque CA, de Cook AW 2004. Molecular phylogeny and taxonomy of the genus Pythium. Mycol Res 108:1363-1383.

Lilley JH, Hart D, Panyawachira V, Kanachanakhan S, Chinabut S, Soderhall K, Cerenius K 2003. Molecular characterization of the fish-pathogenic fungus Aphanomyces invadans. J Fish Dis 26:263-275.

Marquardt WC, Speer CA 2001. Apicocomplexa. Encylopedia of Life Sciences (ELS). Wiley InterScience. http://mrw.interscience.wiley.com/emrw/9780470015902/ els/article/a0001956/current/html, DOI: 10.1038/npg.els.0001956.

Martin WW 1977. The development and possible relationships of a new Atkinsiella parasitic in insect eggs. Am J Bot 64:760-769.

Massana R, Castresana J, Balagué V, Guillou L, Romari K, Groisillier A, Valentin K, Pedró-Alió C 2004. Phylogenetic and ecological analysis of novel marine stramenopiles. App Environ Microbiol 70:3528-3534.

Massana R, Terrado R, Forn I, Lovejoy C, Pedró-Alió C 2006. Distribution and abundance of uncultured heterotrophic flagellates in the world oceans. Envir Microbiol 8:1515-1522.

Müller DG, Küpper, FC, Küpper H 1999. Infection experiments reveal broad host ranges of Eurychasma dicksonii (Oomycota) and Chytridium polysiphoniae (Chytridiomycota), two eukaryotic parasites in marine brown algae (Phaeophyceae). Phycol Res 47:217-223.

Nakagiri A 2002. Diversity and phylogeny of Halophytophthora (Oomycetes). Abstracts 7th Int. Mycol. Cong. Oslo. 55 p. 19.

Newell SY, Cefalu R, Fell JW 1977. Myzocytium, Haptoglossa and Gonimochaete (fungi) in littoral marine nematodes. Bull Mar Sci 27:197-207.

Padgett DE 1978. Observations on the estuarine distribution of Saprolegniceae. Trans Br Mycol Soc 70:141-143.

Patron NJ, Rogers MB, Keeling PJ 2004. Gene replacement of fructose-1,6-bisphosphate aldolase supports the hypothesis of a single photosynthetic ancestor of chromalveolates. Eukaryot Cell 3:1169-1175.

Patterson DJ 1989. Chromophytes from a protistan perspective. In: Green JP, Leadbeater BSC, Diver WL editors. The chromophyte algae: problems and perspectives. Clarendon Press, Oxford, UK. pp. 357-379.

Patterson DJ 1999. The diversity of eukaryotes. Am Nat 65:S96-S124.

Petersen AB, Rosendahl S 2000. Phylogeny of the Peronosporomycetes (Oomycota) based on partial sequences of the large ribosomal subunit (LSU rDNA). Mycol Res 104:1295-1303.

Prakob W, Judelson HS 2007. Gene expression during oosporogenesis in heterothallic and homothallic Phytophthora. Fungal Genet Biol 44:726-739.

Pueschel CM, Van der Meer JP 1985. Ultrastructure of the fungus Petersenia palmariae (Oomycota) parasitic on the alga Palmaria molis (Rhodophyceae). Can J Bot 63: 409-418. 
Raghu Kumar C 1980. An ultrastructural study of the marine diatom Licmophora hyalina and its parasite Ectrogella perforans. II. Development of the fungus in its host. Can J Bot 58:2557-2574.

Richards TA, Dacks JB, Jenkinson JM, Thornton CR, Talbot NJ 2006. Evolution of filamentous pathogens: gene exchange across eukaryote kingdoms. Curr Biol 16:1857-1864.

Riethmüller A, Voglmayr H, Göker M, Weiss M, Oberwinkler F 2002. Phylogenetic relationships of the downy mildews (Peronosporales) and related groups based on nuclear large subunit ribosomal DNA sequences. Mycologia 94:834-849.

Riethmüller A, Weiss M, Oberwinkler F 1999. Phylogenetic studies of Saprolegniomycetidae and related groups based on nuclear large subunit ribosomal DNA sequences. Can J Bot 77:1790-1800.

Robold A, Hardham AR 2005. During attachment Phytophthora spores secrete proteins containing thrombospondin type 1 repeats. Curr Genet 47:307-315.

Schnepf E, Deichgräber G, Drebes G 1977. Development and ultrastructure of the marine, parasitic oomcete, Lagenisma coscinodisci (Lagenidiales): sexual reproduction. Can J Bot 56:1315-1325.

Schnepf E, Deichgräber G, Drebes G 1978. Development and ultrastructure of the marine, parasitic oomycete, Lagenisma coscinodisci Drebes (Lagenidiales). The infection. Arch Microbiol 116:133-139.

Schnepf E, Schweikert M 1997. Pirsonia, phagotrophic nanoflagellate incertae sedis, feeding on marine diatoms: attachment, fine structure and taxonomy. Arch Protistenk 147:361-371.

Sekimoto S 2008. The taxonomy and phylogeny of the marine holocarpic oomycetes. Ph.D. Thesis, Graduate School of Natural Sciences, Konan University, Kobe.

Sekimoto S, Beakes GW, Gachon CMM, Müller DG, Küpper FC, Honda D 2008b. The development, ultrastructural cytology, and molecular phylogeny of the basal oomycete Eurychasma dicksonii, infecting the filamentous phaeophyte algae Ectocarpus siliculosus and Pylaiella littoralis. Protist 159:401-412.

Sekimoto S, Hatai K, Honda D 2007. Molecular phylogeny of an unidentified Haliphthoros-like marine oomycete and Haliphthoros milfordensis inferred from nuclear-encoded small and large subunit rDNA genes and mitochondrial-encoded cox2 gene. Mycoscience 48:212-221.

Sekimoto S, Kochkova TA, West JA, Beakes, GW, Honda D 2009. Olpidiopsis bostrychiae: a new species endoparasitic oomycete that infects Bostrychia and other red algae. Phycologia In Press.

Sekimoto S, Yokoo K, Kawamura Y, Honda D 2008a. Taxonomy, molecular phylogeny, and ultrastructural morphology of Olpidiopsis porphyrae sp. nov. (Oomycetes, stramenopiles), a unicellular obligate endoparasite of Porphyra spp. (Bangiales, Rhodophyta). Mycol Res 112:361-374.

Sparrow FK 1960. Aquatic phycomycetes, 2nd ed. University of Michigan Press, Ann Arbor.

Sparrow FK 1976. The present status of classification in biflagellate fungi. In: GarethJones EB, editor. Recent advances in aquatic mycology. Elek Science, London, pp. 213-222. 
Spencer MA, Vick MC, Dick MW 2002. Revision of Aplanopsis, Pythiopsis, and 'subcentric' Achlya species (Saprolegniaceae) using 18S rDNA and morphological data. Mycol Res 106:549-560.

Talbot NJ 2007. Deadly special deliveries. Nature 450:41-42.

Thines M, Göker M, Telle S, Ryley M, Mathur K, Narayana YD, Spring O, Thakur RP 2008. Phylogenetic relationships in graminicolous downy mildews based on cox 2 sequence data. Mycol Res 112:345-351.

Torto-Alalibo T, Tian M, Gajendran K, Waugh ME, Van West P, Kamoun S 2005. Expressed sequence tags from the oomycete fish pathogen Saprolegnia parasitica reveal putative virulence factors. BMC Microbiol 5:46.

Tsui CKM, Marshall W, Yokoyama R, Honda D, Craven KL, Peterson PD, Lippmeier JC, Berbee ML 2008. Labyrinthulomycetes phylogeny and its implication for the evolutionary loss of chloroplasts and gain of ectoplasmic gliding. Molec. Phylogen Evol. In press.

Voglmayer H, Riethmüller A 2006. Phylogenetic relationships of Albugo species (white blister rusts) based on LSU rDNA sequence and oospore data. Mycol Res 110:75-85. 